Review

\title{
Systematic Review of Metabolic Syndrome Biomarkers: A Panel for Early Detection, Management, and Risk Stratification in the West Virginian Population
}

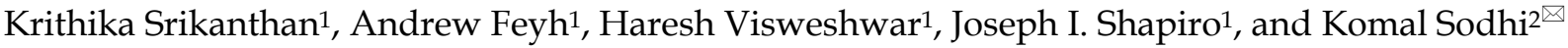 \\ 1. Department of Internal Medicine, Joan C. Edwards School of Medicine, Marshall University, USA \\ 2. Department of Surgery and Pharmacology, Joan C. Edwards School of Medicine, Marshall University, USA \\ $\square$ Corresponding author: Komal Sodhi, M.D., Assistant Professor of Surgery and Pharmacology, Marshall University Joan C Edwards School of Medicine, WV \\ 25701, Tel: 304 691-1704, Fax: 914 347-4956, E-mail: Sodhi@marshall.edu \\ (0) Ivyspring International Publisher. Reproduction is permitted for personal, noncommercial use, provided that the article is in whole, unmodified, and properly cited. See \\ http://ivyspring.com/terms for terms and conditions.
}

Received: 2015.09.09; Accepted: 2015.11.09; Published: 2016.01.01

\begin{abstract}
Introduction: Metabolic syndrome represents a cluster of related metabolic abnormalities, including central obesity, hypertension, dyslipidemia, hyperglycemia, and insulin resistance, with central obesity and insulin resistance in particular recognized as causative factors. These metabolic derangements present significant risk factors for cardiovascular disease, which is commonly recognized as the primary clinical outcome, although other outcomes are possible. Metabolic syndrome is a progressive condition that encompasses a wide array of disorders with specific metabolic abnormalities presenting at different times. These abnormalities can be detected and monitored via serum biomarkers. This review will compile a list of promising biomarkers that are associated with metabolic syndrome and this panel can aid in early detection and management of metabolic syndrome in high risk populations, such as in West Virginia.

Methods: A literature review was conducted using PubMed, Science Direct, and Google Scholar to search for markers related to metabolic syndrome. Biomarkers searched included adipokines (leptin, adiponectin), neuropeptides (ghrelin), pro-inflammatory cytokines (IL-6, TNF- $\alpha$ ), anti-inflammatory cytokines (IL-10), markers of antioxidant status (OxLDL, PON-1, uric acid), and prothrombic factors (PAI-1).

Results: According to the literature, the concentrations of pro-inflammatory cytokines (IL-6, TNF- $\alpha$ ), markers of pro-oxidant status (OxLDL, uric acid), and prothrombic factors (PAI-1) were elevated in metabolic syndrome. Additionally, leptin concentrations were found to be elevated in metabolic syndrome as well, likely due to leptin resistance. In contrast, concentrations of anti-inflammatory cytokines (IL-10), ghrelin, adiponectin, and antioxidant factors (PON-1) were decreased in metabolic syndrome, and these decreases also correlated with specific disorders within the cluster.

Conclusion: Based on the evidence presented within the literature, the aforementioned biomarkers correlate significantly with metabolic syndrome and could provide a minimally-invasive means for early detection and specific treatment of these disorders. Further research is encouraged to determine the efficacy of applying these biomarkers to diagnosis and treatment in a clinical setting.
\end{abstract}

Key words: Metabolic syndrome, literature review

\section{Introduction}

Metabolic syndrome is a cluster of metabolic abnormalities which confers upon an individual a substantial increase in cardiovascular disease (CVD) risk - approximately twice as high as those without the syndrome. Compared to those without metabolic syndrome, those with it are at an increased risk of mortality from CVD, coronary heart disease, stroke, vascular dysfunction, and all-cause mortality [1]. While the pathogenesis of metabolic syndrome and its components is not well understood, central obesity 


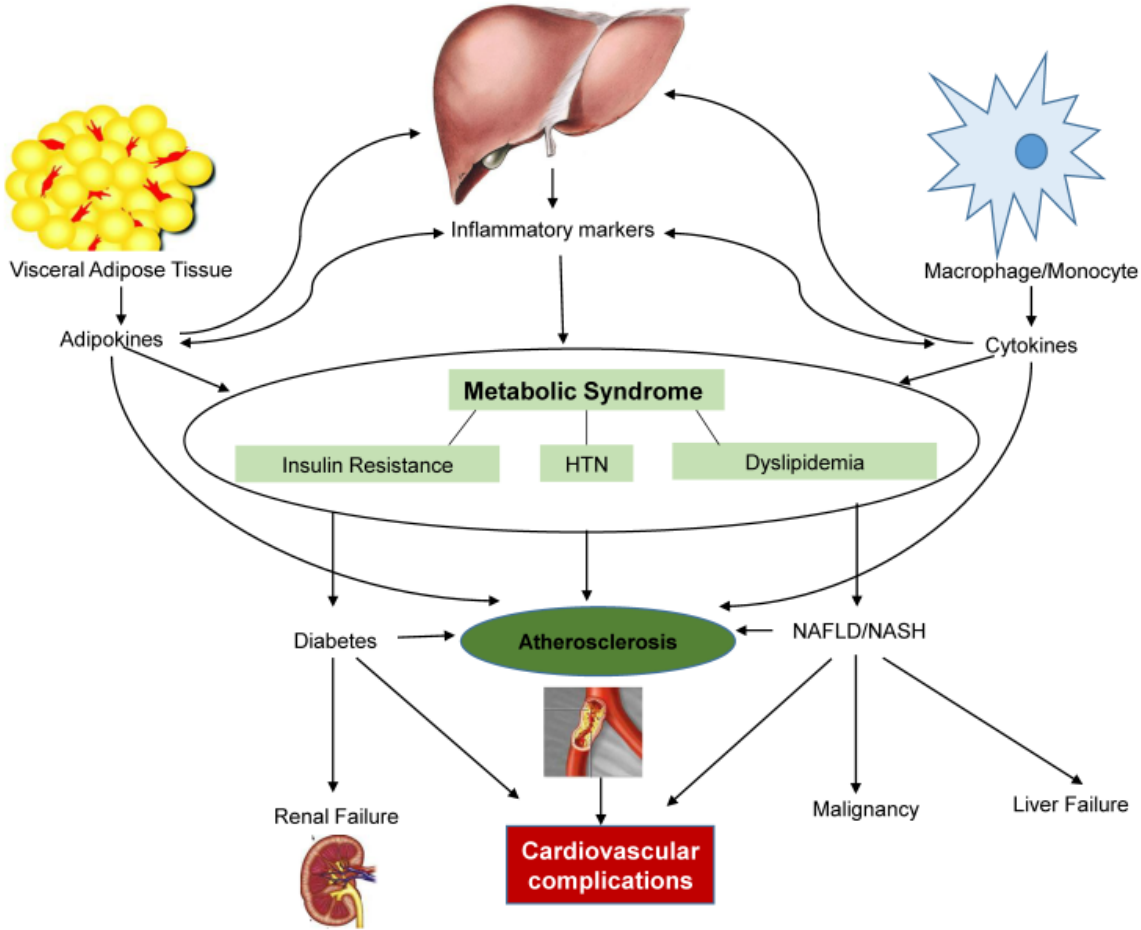

Figure 1: Interaction of adipokines, cytokines, and inflammatory markers that contribute to the development of metabolic syndrome and its complications. HTN-Hypertension, NAFLD/NASH- Nonalcoholic fatty liver disease/nonalcoholic steatohepatitis

and insulin resistance are recognized as causative factors. Several different organizations have outlined diagnostic criteria for metabolic syndrome, which designates values for obesity (waist circumference or BMI), triglyceride levels, HDL (High Density Lipo- protein) levels, hypertension, hyperglycemia, and sometimes urine albumin or albumin: creatinine ratio (Table 1). Based on AHA criteria, nearly $35 \%$ of US adults, and $50 \%$ of those older than 60 years old, have metabolic syndrome [2]. Regardless of which criteria are used, the primary concern is early detection of potential CVD complications and early intervention $[3,4]$.

Though the NCEP ATP III report and WHO have both identified CVD as the primary clinical outcome of metabolic syndrome, most people with metabolic syndrome will have insulin resistance, which results in increased risk for type 2 diabetes (Figure 1). Once diabetes becomes clinically apparent, CVD risk rises sharply. In addition to CVD and type 2 diabetes, individuals with metabolic syndrome are seemingly more susceptible to other conditions, including polycystic ovary syndrome, fatty liver, cholesterol gallstones, asthma, sleep disturbances, and some forms of cancer, such as breast, pancreatic, colorectal, and prostate [5, 6].

Table 1: Diagnostic Criteria for Metabolic Syndrome

\begin{tabular}{|c|c|c|c|c|c|}
\hline & IDF (Obesity $+\geq 2$ ) & $\operatorname{AHA}(\geq 3)$ & NCEP ATP III ( $\geq 3)$ & $\begin{array}{l}\text { WHO(Insulin re- } \\
\text { sistance/Diabetes }+\geq 2 \text { ) }\end{array}$ & $\begin{array}{l}\text { EGIR(hyperinsulinemia } \\
+\geq 2 \text { ) }\end{array}$ \\
\hline Obesity & $\begin{array}{l}\text { BMI }>30 \mathrm{~kg} / \mathrm{m}^{2} \text { or specific } \\
\text { gender and ethnicity waist } \\
\text { circumference cutoffs }\end{array}$ & $\begin{array}{l}\text { Waist circumference for } \\
\text { males }>40 \mathrm{in} \text {, females }>35 \text { in }\end{array}$ & $\begin{array}{l}\text { Waist circumference for males } \\
>40 \mathrm{in}, \text { females }>35 \mathrm{in}\end{array}$ & $\begin{array}{l}\text { Waist } / \text { hip ratio }>0.9 \text { in males } \\
\text { and }>0.85 \text { in females or } \\
\text { BMI }>30 \mathrm{~kg} / \mathrm{m}^{2}\end{array}$ & $\begin{array}{l}\text { Waist circumference for } \\
\text { males } \geq 94 \mathrm{~cm} \text {, fe- } \\
\text { males } \geq 80 \mathrm{~cm}\end{array}$ \\
\hline $\begin{array}{l}\text { Elevated Tri- } \\
\text { glycerides }\end{array}$ & $\begin{array}{l}\mathrm{TG} \geq 150 \mathrm{mg} / \mathrm{dL} \text { or treatment of } \\
\text { this lipid abnormality }\end{array}$ & $\begin{array}{l}\text { Fasting TG } \geq 150 \mathrm{mg} / \mathrm{dL} \text { or } \\
\text { treatment of this lipid ab- } \\
\text { normality }\end{array}$ & $\begin{array}{l}\mathrm{TG}>150 \mathrm{mg} / \mathrm{dL} \text { or treatment } \\
\text { of this lipid abnormality }\end{array}$ & $\mathrm{TG} \geq 150 \mathrm{mg} / \mathrm{dL}$ & $\mathrm{TG} \geq 177 \mathrm{mg} / \mathrm{dL}$ \\
\hline Decreased HDL & $\begin{array}{l}\mathrm{HDL}<40 \mathrm{mg} / \mathrm{dL} \text { in males and } \\
<50 \mathrm{mg} / \mathrm{dL} \text { in females or } \\
\text { specific treatment for this lipid } \\
\text { abnormality }\end{array}$ & $\begin{array}{l}\mathrm{HDL}<40 \mathrm{mg} / \mathrm{dL} \text { in males and } \\
<50 \mathrm{mg} / \mathrm{dL} \text { in females or } \\
\text { treatment for this lipid ab- } \\
\text { normality }\end{array}$ & $\begin{array}{l}\mathrm{HDL}<40 \mathrm{mg} / \mathrm{dL} \text { in males and } \\
<50 \mathrm{mg} / \mathrm{dL} \text { in females or } \\
\text { treatment for this lipid ab- } \\
\text { normality }\end{array}$ & $\begin{array}{l}\mathrm{HDL}<35 \mathrm{mg} / \mathrm{dL} \text { in males and } \\
<39 \mathrm{mg} / \mathrm{dL} \text { in females }\end{array}$ & $\mathrm{HDL}<39 \mathrm{mg} / \mathrm{dL}$ \\
\hline Hypertension & $\begin{array}{l}\mathrm{SBP} \geq 130 \text { or } \mathrm{DBP} \geq 85 \mathrm{~mm} \mathrm{Hg} \\
\text { or treatment of previously } \\
\text { diagnosed hypertension }\end{array}$ & $\begin{array}{l}\mathrm{BP}>130 / 85 \mathrm{~mm} \mathrm{Hg} \text { or taking } \\
\text { medication for hypertension }\end{array}$ & $\begin{array}{l}\mathrm{SBP} \geq 130 \text { or } \mathrm{DBP} \geq 85 \mathrm{~mm} \mathrm{Hg} \\
\text { or taking medication for } \\
\text { hypertension }\end{array}$ & $\geq 140 / 90 \mathrm{~mm} \mathrm{Hg}$ & $\begin{array}{l}\geq 140 / 90 \mathrm{~mm} \mathrm{Hg} \text { or } \\
\text { taking medication for } \\
\text { hypertension }\end{array}$ \\
\hline Hyperglycemia & $\begin{array}{l}\text { Fasting plasma glucose } \\
>100 \mathrm{mg} / \mathrm{dL} \text { or previously } \\
\text { diagnosed type } 2 \text { diabetes }\end{array}$ & $\begin{array}{l}\text { Fasting glucose }>100 \mathrm{mg} / \mathrm{dL} \\
\text { or taking medicine for high } \\
\text { glucose }\end{array}$ & $\begin{array}{l}\text { Fasting glucose }>100 \mathrm{mg} / \mathrm{dL} \\
\text { or taking medicine for high } \\
\text { glucose }\end{array}$ & Insulin resistance required & $\begin{array}{l}\text { Insulin resistance re- } \\
\text { quired(plasma insulin } \\
>75^{\text {th }} \text { percentile) }\end{array}$ \\
\hline Other & & & & $\begin{array}{l}\text { Urine albumin } \geq 20 \mu \mathrm{g} / \mathrm{min} \text { or } \\
\text { Albumin: creatinine ratio } \geq \\
30 \mathrm{mg} / \mathrm{g}\end{array}$ & \\
\hline
\end{tabular}

IDF- International Diabetes Federation, AHA- American Heart Association, NCEP ATP III- National Cholesterol Education Program-Adult Treatment Panel III, WHOWorld Health Organization, EGIR- European Group for the Study of Insulin Resistance, BMI- Body Mass Index, SBP - Systolic Blood pressure, DBP- Diastolic Blood Pressure, BP - Blood Pressure, TG- Triglycerides, HDL-High Density Lipoprotein 
Based on "The state of obesity: 2014 report", West Virginia ranks highest in the country for obesity prevalence $(35.1 \%)$ in the adult population. $\mathrm{WV}$ is also highest-ranked for prevalence of hypertension (41\%), and ranked second for prevalence of diabetes $(13 \%)$ in the adult population. Given the extent of disease burden in our state, it can be inferred that West Virginia also has one of the highest prevalences, if not the highest, of metabolic syndrome and subsequent complications, though no epidemiological data is available through a literature search on PubMed. It is imperative to find a way to decrease these complications, and early detection is paramount to this process, yet frequently diagnosis is only possible once complications have already begun.

Research shows that adipocytes produce bioactive substances, known as adipocytokines or adipokines. Accumulation of adipocytes leads to the dysregulated production of adipokines, which contributes to the development of metabolic syndrome [7]. The list of these dysregulated adipokines and cytokines is constantly growing and is a reflection of the heterogeneity of adipose tissue due to the number of resident cell types [8].

The mechanism by which adipose accumulation elucidates dysregulation is not entirely clear at this time, but some suggest that it is at least partly due to systemic oxidative stress brought on by obesity [9]. One proposed mechanism by which obesity produces oxidative stress is mitochondrial and peroxisomal oxidation of fatty acids, which can generate reactive oxygen species (ROS) in oxidation reactions. Malondialdehyde (MDA), a lipid peroxidation end product, is increased in conditions marked by obesity and insulin resistance. It is able to enhance expression of pro-inflammatory cytokines, resulting in systemic stress [10]. In addition to MDA, F-2 isoprostanes (F2-IsoPs) are also a product of polyunsaturated fatty acid peroxidation. A study has shown that BMI is significantly correlated with the F2-IsoP concentration. Another marker of oxidative stress is urinary 8-iso prostaglandin F2a (8-iso PGFa). It has been shown to be positively correlated with obesity and insulin resistance [11].

For many pathological states, medicine relies on biomarkers to aid in diagnosis and management when overt clinical signs or gross anatomic abnormalities are absent or are not obvious. In addition to this, biomarkers can identify individuals within a population susceptible to disease on the basis of a "genotype" rather than on a reported history. Biomarkers also afford the ability to quantify this susceptibility, allowing for an estimation of disease risk for a population [12].

A panel of metabolic syndrome biomarkers could provide a relatively easy, minimally-invasive means of identifying those who are at risk for developing metabolic syndrome and subsequent complications. A panel, rather than just individual biomarkers, would be useful since biomarkers can have multiple roles and pathways in which they are involved, so it would be difficult to say that one biomarker alone is sensitive and specific for the diagnosis of metabolic syndrome. Furthermore, many of these biomarkers are interrelated in how they play a role in metabolic syndrome, so correlations between biomarkers would be helpful to assess patients. With this early detection, early intervention is also possible and could be an effective means to diminish the widespread effects this syndrome has on the West Virginian population, as well as on others. A panel could also provide a mechanism to personalize treatment given the etiology differences amongst individuals. While there are numerous articles listing the biomarkers, both established and emerging, this review will compile a panel of the most researched biomarkers and provide evidence of their relation to metabolic syndrome. This panel could provide a way to diagnose, risk stratify, monitor and potentially treat individuals at the molecular level.

\section{Methods}

A literature review was performed using PubMed, Science Direct, and Google Scholar from commencement to present and last search was done August 25, 2015. All databases were searched for the following keywords in varying combinations: "biomarkers", "metabolic syndrome", "leptin", "adiponectin", "uric acid", "leptin/adiponectin ratio", "plasminogen activator one", "Interleukin 6 (IL-6)", "Interleukin 10 (IL-10)", "ghrelin", "tumor necrosis factor(TNFa)", "paraoxonase", "oxidized LDL", "weight loss", and "medications".

\section{Results}

\section{Leptin}

Leptin is an adipokine, which under normal physiological conditions functions to reduce appetite, increase energy expenditure, increase sympathetic activity, facilitate glucose utilization, and improve insulin sensitivity [13]. It is expressed in levels proportionate to adipose mass, and though it is produced mostly by adipocytes, it is also produced by vascular smooth muscle cells, cardiomyocytes, and placenta in pregnant women. The functional leptin receptor is in the hypothalamus where it functions to increase energy expenditure and reduce appetite. The receptor is also found in other organs such as the heart, liver, kidneys, and pancreas; it is also present in the smooth 
muscle and endothelium of heart, brain vasculature, and myometrium [14]. Given the wide range of targets for leptin based on receptor locations, the effects of it are also widespread. Leptin has a functional receptor, $\mathrm{Ob}-\mathrm{Rb}$, in the myocardium, and studies have shown a direct link between leptin and myocardial structural remodeling [15]. There is controversy as to whether leptin causes or protects from left ventricular hypertrophy $(\mathrm{LVH})$ as research has shown mixed results, though more suggest it contributes to LVH [14, 16]. Independent of conventional risk factors, studies have shown that leptin can predict myocardial infarction [17]. Leptin also affects vascular structure by promoting hypertension, angiogenesis, and atherosclerosis [14].

Leptin's role as a biomarker for metabolic syndrome has been researched in different populations. Regardless of which demographic studied, elevated leptin levels are associated with metabolic syndrome. This is not surprising given that elevated leptin is associated with obesity, insulin resistance, myocardial infarction, and congestive heart failure [14]. Yoshinaga et al found that leptin was the most sensitive marker for predicting metabolic syndrome (and cardiovascular risk) in elementary school children [18]. Lee et al found that leptin was elevated in postmenopausal women with metabolic syndrome. They found a positive correlation with leptin and abdominal obesity (one of the components of metabolic syndrome), and with the number of components of metabolic syndrome present [19]. A study of a Lebanese population, which focused on nondiabetic males over fifty years old, also found elevated leptin levels associated with metabolic syndrome. This study found that leptin was strongly correlated with waist size, but was only weakly correlated with lipid profile, which disappeared with BMI adjustment [20]. Similar findings of elevated leptin associated with metabolic syndrome, independent of BMI, were found in a Korean population. In this study by Yun et al, serum leptin levels increased as the components of metabolic syndrome increased, regardless of obese and nonobese weight status, implying that reduction of leptin levels may be protective, regardless of weight loss [21]. Contrary to this, Martins et al, found a direct positive association between leptin and obesity, hyperinsulinemia and insulin resistance, but was only weakly related to other components of metabolic syndrome [22]. Though there is some dissension in the literature about whether leptin is associated with metabolic syndrome independent of BMI, the general consensus is that it is elevated in metabolic syndrome in children, the elderly, females, and males, and therefore can serve as an effective biomarker on a screening panel.

\section{Adiponectin}

Adiponectin, like leptin, is an adipose-derived plasma protein with widespread effects. However, unlike leptin, it is secreted exclusively from adipocytes [23]. The different forms of adiponectin include low molecular weight trimer, middle molecular weight hexamer, and high molecular weight (HMW). The HMW form is believed by many to be the more active form and has the most favorable metabolic effects on insulin sensitization and protection against diabetes [14, 23, 24]. Adiponectin has many functions, including anti-atherogenesis, insulin sensitization, lipid oxidation enhancement, and vasodilatation. Therefore, it stands to reason that it is related to metabolic syndrome given its impact on all of these components. It suppresses almost all processes involved in atherosclerotic vascular change: the expression of adhesion molecules in vascular endothelial cells, adhesion of monocytes to endothelial cells (via TNF-a inhibition), vascular smooth muscle cell proliferation and migration, and foam cell formation (via oxidized LDL (OxLDL) inhibition) [25]. It has insulin-sensitizing activities, with high levels exerting a protective effect against type 2 diabetes in diabetes-prone individuals [7] and low levels being an independent risk factor for future development of type 2 diabetes [26]. Levels of adiponectin are low in subjects with essential hypertension and in the obese, but adiponectin levels can be increased with weight loss $[7,27]$.

A study of Japanese adults by Ryo et al showed that adiponectin levels were negatively correlated with waist circumference, visceral fat, serum triglycerides, fasting plasma glucose, fasting plasma insulin, and systolic and diastolic blood pressure in males and females, and positively correlated with HDL. As the mean number of metabolic syndrome components increased, plasma adiponectin levels decreased. They found that men had lower levels of adiponectin than women, which is interesting since it may be part of the reason why women have a lower risk of coronary artery disease [7]. Gannage et al found adiponectin to be inversely correlated with metabolic syndrome, independent of BMI as other studies have also shown in the past $[20,28]$. Santaneimi et al studied a Finnish population and found decreasing adiponectin levels correlated with an increasing number of components of metabolic syndrome in both sexes, and this was once again independent of BMI [27]. Overall, the literature shows that adiponectin is inversely related to metabolic syndrome and the number of components present. However, many believe HMW adiponectin to be the more active form and Falahi et al suggest that HMW adiponectin may even be the most reliable biomarker for metabolic syndrome diagnosis [29]. 
Hara et al found that the ratio of HMW adiponectin to plasma adiponectin was an even better predictor of insulin resistance and metabolic syndrome [30]. Therefore, adiponectin, and preferably HMW adiponectin, should be considered on a panel of biomarkers for metabolic syndrome diagnosis.

\section{Leptin: Adiponectin Ratio}

Other studies have determined that the leptin: adiponectin ratio (LAR) is more beneficial than either alone. Falahi et al showed that a high LAR is a better biomarker than leptin or adiponectin alone for the diagnosis of metabolic syndrome [29]. A study of Japanese patients found that LAR was significantly and positively associated with the number of components of metabolic syndrome present, and the ratio was independently associated with each component of metabolic syndrome [31]. However there may be differences to this between males and females. Cicero et al found the LAR to be strongly associated with metabolic syndrome, especially in males. The association was weaker in females since they had more elevated adiponectin levels, which is thought to be protective against metabolic syndrome [32]. Others postulate that the ratio difference between males and females is due to the difference in glucose and lipid metabolism [31]. One limiting factor with using just adiponectin or leptin is that the difference between adiponectin and leptin tends to be small in the fasting vs postprandial state. Therefore, one of the benefits of using the LAR is that it has the potential to assess insulin sensitivity and metabolic syndrome in the nonfasting state [33].

\section{Ghrelin}

Ghrelin is a neuroendocrine hormone secreted primarily by the stomach that stimulates appetite directly via activation of the $\mathrm{GH}$ secretagogue receptor 1a (GHSR-1a) in the hypothalamus, and indirectly by increasing expression of orexigenic peptides, such as neuropeptide Y (NPY) [34, 35]. It may also be protective of vasculature by antagonizing the effects of vasoconstrictors, such as endothelin 1 , and promoting the effects of vasodilators, such as nitric oxide (NO) [36]. Furthermore, it can help to promote lipolysis via stimulation of hypothalamic AMP-activated protein kinase (AMPK) [35]. Research into the vasoprotective and lipolytic properties of ghrelin is emerging and presents two pathways by which ghrelin can exert a protective effect against metabolic syndrome.

Metabolic syndrome is associated with lower levels of ghrelin, and progressively lower ghrelin levels are associated with increasing metabolic syndrome severity. Ghrelin levels decrease with increasing number of metabolic syndrome derangements [37-40].
This trend is significant even after adjusting for age and sex, though ghrelin levels have been shown to be higher in females than males [37, 38]. Low ghrelin levels have been associated with the components of metabolic syndrome including obesity, insulin resistance, and hypertension [41-43]. However the association between low ghrelin and metabolic syndrome is likely primarily explained by the relationship to obesity as obese patients with metabolic syndrome have lower ghrelin levels than nonobese counterparts [44]. Furthermore, amongst obese patients, ghrelin levels are lower in insulin resistant patients compared to insulin sensitive obese patients [45]. Plasma ghrelin levels are also decreased in the healthy offspring of type 2 diabetes patients suggesting a genetic component to ghrelin regulation [37]. Ghrelin is implicated in endothelial function by preventing proatherogenic changes and improving vasodilation [37]. Tesauro et al assessed vascular function by measuring forearm blood flow in metabolic syndrome and control patients. They showed that exogenous ghrelin significantly reduced the vasoconstrictor effects of endothelin 1 and enhanced the vasodilator effects of $\mathrm{NO}$ in metabolic syndrome patients, but did not have a significant effect on vascular tone in control patients [36]. Given ghrelin's relation to each of the components of metabolic syndrome, to metabolic syndrome itself, and the potential to note abnormal levels in healthy individuals with genetic predispositions, it would be an effective biomarker for metabolic syndrome.

\section{Plasminogen Activator Inhibitor - 1}

Plasminogen Activator Inhibitor-1 (PAI-1) is the primary of four serine peptidase inhibitors that functions to modulate extracellular matrix remodeling and fibrinolysis. It binds to and deactivates tissue plasminogens (tissue type plasminogen activator (tPA), urokinase plasminogen activator (uPA)). tPA is thought to be responsible for intravascular plasminogen activation, with fibrin regulating its activity, and uPA is responsible for plasminogen activation on migrating cells, with the uPA receptor regulating its activity on different cells. Thus, PAI-1 can inhibit intravascular fibrinolysis and cell-associated proteolysis [46].

Under physiologic conditions, PAI-1 is secreted into the circulation or extracellular space by endothelial cells, adipocytes, vascular smooth muscle cells, platelets, or hepatocytes. Under pathologic conditions however, PAI1 is induced by many pro-inflammatory and pro-oxidant factors. For example, when TNF-a, transforming growth factor beta (TGF- $\beta$ ), angiotensin II, glucocorticoids, and insulin are elevated, adipocytes are stimulated to increase PAI-1 levels. Hypoxia 
and ROS also increase PAI-1 levels. Elevated levels of PAI-1 consequently effect vasculature, inflammatory signaling, adiposity, and insulin resistance [47].

Aberrant PAI-1 levels are associated with several pathological diseases. For example, high levels are positively correlated with thrombotic vascular conditions such as myocardial infarction and deep vein thrombosis. This is thought to be related to the inhibition of fibrin degradation and vessel wall remodeling. It is thought to be a strong risk factor for coronary artery disease and some suggest it can be used as an independent risk factor for cardiovascular risk [48, 49]. It has also been implicated in cancer angiogenesis and metastasis, wound healing, bacterial infections, rheumatoid arthritis, and chronic kidney disease [50].

The link between PAI-1 and metabolic syndrome has been long established with elevated levels being strongly correlated such that the more severe the metabolic syndrome, the higher the PAI-1 [51-53]. Kraja et al showed that PAI-1 was strongly associated with the components of metabolic syndrome, including BMI, triglycerides and insulin resistance [47]. Interestingly, several groups have found that PAI-1 levels are not associated with dyslipidemia but rather with the distribution phenotype of adipocytes: visceral adipose tissue primarily and ectopic fat in the liver [54, 55]. Given this, some suggest PAI-1 can serve as a biomarker for ectopic fat storage. Like several of the other metabolic syndrome biomarkers, differences between the sexes have been noted, with the relationship being stronger in males than females [55]. PAI-1 levels decrease with calorie restriction, weight loss, decrease in body fat, and when insulin resistance improves $[46,56]$. Treatment with insulin-sensitizing drugs decreases PAI-1 in patients with diabetes and to some extent in otherwise healthy obese individuals [57].

\section{Uric Acid}

Uric acid is an endogenously produced terminal degradation product of purine catabolism, formed by the liver and excreted by the kidneys primarily and intestines secondarily. Uric acid has antioxidant capacities extracellularly and can be responsible for $2 / 3$ of the total plasma antioxidant capacity, where it chelates metals and scavenges oxygen radicals. However, intracellularly, it has pro-inflammatory and pro-oxidant activity. It has been shown that uric acid is a circulating marker for oxidative damage in conditions like ischemic liver, atherosclerosis, diabetes, and chronic heart failure [58]. As a pro-oxidant, under ischemic conditions or as a result of tissue damage, uric acid oxidizes lipids, which results in inflammation that disrupts reverse cholesterol transport [59]. It also decreases the availability of nitric oxide, which results in less vasodilation and more reactive oxygen species (ROS). This, coupled with its ability to stimulate monocytes to produce TNF- $\alpha$, creates a pro-inflammatory state found in metabolic syndrome. Though its role in pathological diseases is not completely understood, uric acid likely causes systemic inflammation [58].

Hyperuricemia is a well-known risk factor for atherosclerotic events like myocardial infarction and stroke, and is associated with other cardiovascular risk factors like hypertension and dyslipidemia. Ishizaka et al also found a positive correlation between uric acid and BMI, blood pressure, and triglycerides, and a negative correlation with HDL-C [60]. Silva et al shows that uric acid levels are significantly elevated in males with abdominal obesity and females with abdominal obesity, low HDL-C, and hypertension [61]. It is also suggested that hyperuricemia is a marker of insulin resistance, as some studies have shown that decreasing insulin resistance by diet or medications decreases uric acid levels [62-64]. Among dietary causes of hyperuricemia, excess consumption of fructose via added sucrose or high-fructose corn syrup is of particular interest, as this dietary component has also been implicated in metabolic syndrome. According to Khitan and Kim, fructose metabolism is initiated by an enzyme called ketohexokinase (KHK), also known as fructokinase. This ATP-dependent step in fructose metabolism lacks a negative feedback mechanism, so in the event of excessive fructose consumption, ATP is rapidly depleted and many of the dephosphorylated adenosine compounds are catabolized, resulting in increased uric acid [65]. Johnson et al demonstrated a link between fructose-induced hyperuricemia and an increased incidence of metabolic syndrome and some of its features, including obesity, hypertension, and insulin resistance [66].

Given the relation of uric acid and all the components of metabolic syndrome, it is expected that uric acid would be elevated for metabolic syndrome as a whole as well. Ishizaka et al investigated the relationship between uric acid and metabolic syndrome and found there to be a graded increase in the prevalence of metabolic syndrome with increasing uric acid in both sexes, though there are differences in the levels between males and females [60]. Levels of uric acid increase with age: in women of childbearing age, levels are lower, but increase to similar levels as males when postmenopausal [67]. Several studies have shown that uric acid levels are significantly elevated in individuals with metabolic syndrome, increases with the number of components of the condition, and is an indicator of worse cardiovascular risk profile [61, $68,69]$. It is estimated that individuals with a high uric 
acid have an odds ratio of 1.6-fold higher for developing metabolic syndrome [70]. The close relationship between uric acid and the presence of metabolic syndrome has been demonstrated in children, adolescents, and adults [71].

Through a search of the published literature to date, uric acid appears to be the only metabolic syndrome biomarker studied in the West Virginian population. Soukup et al studied salivary uric acid as a biomarker for metabolic syndrome and found the relationship to metabolic syndrome and each of its components similar to that of serum uric acid [72]. Similar to other studies, Soukup et al noted a stronger association between uric acid levels and metabolic syndrome in females than in males [72-74]. This is a noninvasive and cost-effective method to diagnose and monitor metabolic syndrome and its components in rural locations, like West Virginia, where health care capabilities are limited.

\section{Interleukin-6}

Interleukin-6 (IL-6) is a pro-inflammatory cytokine that plays a role in the natural inflammatory response. It is often secreted by M1 macrophages as part of the normal inflammatory response against infection and injury [75]. In metabolic syndrome, adipocyte dysfunction is frequently present and is associated with an increase in M1 macrophage population within adipose tissue. This can result in increased secretion of IL-6 and other pro-inflammatory cytokines from adipose tissue. These pro-inflammatory cytokines can then act through a number of cell signaling pathways, including mTOR and Protein Kinase C (PKC) to induce insulin resistance. Through its inflammatory properties it has been implicated in the endothelial cell damage within blood vessels that leads to vascular dysfunction and atherosclerosis. Furthermore, IL-6 can cause aberrant insulin receptor activation, resulting in abnormal insulin signaling cascades, abnormal insulin action, and abnormal glucose metabolism [75].

Studies have shown that elevated levels of IL-6 are associated with metabolic syndrome and increasing levels are associated with more severe metabolic syndrome (assessed by hypertriglyceridemia, hypertension, and fasting glucose levels) [76-78]. Similar to other biomarkers, IL-6 is also associated with each of the components of metabolic syndrome. In a study on postmenopausal women, elevated IL-6 was also associated with abdominal obesity, low HDL, and high triglycerides [77]. Indulekha et al found elevated IL-6 was associated with insulin resistance [78]. In vivo animal studies have shown the effect of IL- 6 on insulin signaling: the administration of IL- 6 to mice resulted in impaired insulin signaling in muscle and liver tissue, leading to hyperglycemia and insulin resistance [79].

IL-6's close association with metabolic syndrome and each of its components suggests that it is an important factor in the progression of metabolic syndrome and would be a good addition to a biomarker panel.

\section{Tumor Necrosis Factor-Alpha}

Tumor Necrosis Factor-Alpha (TNF-a) is a pro-inflammatory cytokine that is secreted by visceral adipose tissue, a common characteristic of metabolic syndrome [80]. Because metabolic syndrome is often characterized by adipocyte dysregulation, and these dysregulated adipocytes tend to secrete TNF- $a$, IL-6, and other pro-inflammatory adipokines at higher levels, the central obesity often encountered in metabolic syndrome could be a risk factor for elevated TNF-a levels [75]. Furthermore, elevated TNF- $\alpha$ levels are associated with insulin resistance via its aberrant activation of the mTOR and PKC signaling pathways [75]. Its contribution to the various characteristics of metabolic syndrome suggest that TNF- $a$ may be a significant contributor to the development and progression of its associated disease processes.

In a study of middle-aged adults with metabolic syndrome, elevated levels of TNF- $\alpha$ and other pro-inflammatory cytokines were associated with insulin resistance and hypertriglyceridemia. The TNF-a, IL-6, and leptin levels in these patients were higher than those levels in the control group, indicating that these cytokines directly correlated with metabolic syndrome [81]. It was hypothesized by Balasoiu et al that early detection of a patient's inflammatory status, including TNF- $\alpha$ and IL-6, could be useful in monitoring and early intervention for metabolic syndrome and its comorbidities [81]. In another study of metabolic syndrome patients with coronary artery disease (CAD), TNF-a levels were found to be significantly higher than the controls [82]. Indulekha et al also found elevated TNF-a levels to be significantly correlated with the presence of metabolic syndrome, and more so in those with insulin resistance [78]. Musialik et al demonstrated elevated levels of soluble TNF-a receptor (sTNFa-R), which is associated with increased TNF- $\alpha$ activity, in patients with metabolic syndrome with hypertension [80]. Because it exerts such widespread systemic effects, TNF-a may contribute to the various disease processes associated with metabolic syndrome.

\section{Interleukin-10}

Interleukin-10 (IL-10) is a predominantly anti-inflammatory cytokine that plays a role in modulating systemic inflammation. Secreted by monocytes or M2 macrophages, one of its functions is to help 
promote normal tissue remodeling following an inflammatory response [75]. One of the methods by which IL-10 moderates the inflammatory response is by inhibiting NADPH oxidase, and therefore the oxidative stress resulting from this enzyme. This has been associated with aberrant insulin receptor substrate (IRS) activation and impaired insulin signaling. Furthermore, the insulin signaling pathway can be dysregulated by abnormal levels of the pro-inflammatory cytokines IL-6 and TNF-a. IL-10 can restore normal insulin signaling by inhibiting NADPH oxidase-induced oxidative stress or by antagonizing the actions of IL- 6 and TNF- $\alpha[75,79]$.

Regarding the role IL-10 plays in insulin signaling, a cross-sectional population study of elderly adults demonstrated that low levels of IL-10 are associated with insulin resistance and type 2 diabetes. Furthermore, the study found that IL-10 levels inversely correlated with levels of total cholesterol, LDL, triglycerides, blood glucose and hemoglobin A1c, and positively correlated with HDL levels [83]. Additionally, in a study on mice treated with IL-6 to induce insulin resistance, in vivo administration of IL-10 demonstrated protection from the impaired insulin signaling that resulted from IL-6 administration, thereby restoring insulin sensitivity and normal glucose metabolism in liver and muscle tissue [79]. Because it antagonizes the pro-inflammatory actions of IL-6 and TNF- $\alpha$, which are both associated with metabolic syndrome and its comorbidities, IL-10 appears to exert a protective effect against increases in these cytokines.

The significance of IL-10 in relation to metabolic syndrome as a whole, rather than its components, however, is a little more complicated. A study of obese children, found IL-10 levels to be elevated in metabolic syndrome, even after BMI was taken into account. Calcaterra et al proposed the elevated levels to be due to the first phase of a complex mechanism in the development of metabolic syndrome in children [84]. Esposito et al studied obese and nonobese women and found IL-10 to be elevated in obese women compared to nonobese women but IL-10 levels were significantly lower in both obese and nonobese women with metabolic syndrome [85]. Others have also shown IL-10 levels to be significantly decreased in those with metabolic syndrome in both males and females [86, 87]. Some have shown that IL-10 levels are significantly correlated with other cytokines like IL-6 and TNF- $a$. Adiponectin is correlated with IL-10 in patients with metabolic syndrome and not the general population [88]. This suggests that if both IL-10 and adiponectin are low, the risk of metabolic syndrome is likely greater. The use of multiple biomarkers in a panel would likely increase the sensitivity and specificity.

\section{Oxidized LDL}

Oxidized LDL (OxLDL) is a product of lipid oxidation and can serve as a marker of oxidative stress. Lipid oxidation contributes to the generation of reactive oxygen species (ROS). These products form components of OxLDL. Lipid oxidation products, ROS, and OxLDL in low concentrations can serve as signaling compounds for pathways of cellular antioxidants, including Heme Oxygenase (HO-1) and glutathione. However, if the antioxidant capacity of the cell is dysfunctional, as is often seen in metabolic syndrome, then these compounds contribute to an oxidative cascade that eventually leads to cell damage and apoptosis [89]. This widespread cell damage and death can contribute to the vascular dysfunction commonly seen in metabolic syndrome, while the dysfunctional OxLDL can further contribute to dyslipidemia, presenting a risk factor for cardiovascular diseases, which are common comorbidities associated with metabolic syndrome. OxLDL contributes to atherosclerosis by invading and damaging the blood vessel endothelium [90]. In addition to cardiovascular disease, elevated levels of OxLDL in adults are associated with obesity and insulin resistance, two common components of metabolic syndrome [91].

Studies have shown that levels of OxLDL are significantly elevated in metabolic syndrome patients and these elevated levels are further associated with reduced arterial elasticity, a risk factor for the development of CAD [90, 92]. Other studies on children associated elevated levels of OxLDL with increased adiposity and insulin resistance. This study suggested that oxidative stress, measured by OxLDL levels, could be a contributing factor to insulin resistance, and that these changes can present early in life [91]. Additionally, a longitudinal study of young adults measured at baseline, 15 years later, and 20 years later demonstrated a significant positive correlation between OxLDL levels and the incidence of metabolic syndrome that arose between the 15-year and 20-year follow-ups. The study also associated elevated OxLDL levels with central obesity, hyperglycemia, and hypertriglyceridemia, all of which are components of metabolic syndrome [93]. The literature suggests that OxLDL serves not only as a promising biomarker for metabolic syndrome detection, but a plausible mechanism by which the components of metabolic syndrome develop and progress.

\section{Paraoxonase}

Paraoxonase-1 (PON-1) is a multipurpose antitoxic and antioxidant enzyme and is believed to contribute to the antioxidant and anti-inflammatory 
properties of HDL $[94,95]$. In particular, it can reduce lipid peroxidation and protect LDL and tissue from oxidative stress [96]. Levels of PON-1 activity correlate with systemic antitoxic and antioxidant capacity, whereas oxidative stress and lipid peroxidation are associated with the onset and progression of metabolic syndrome and some of its comorbidities, particularly vascular dysfunction (resulting from OxLDL) [90]. In low concentrations, OxLDL and ROS serve as signaling compounds in cellular antioxidant pathways, which serve to improve cellular protection mechanisms in the face of oxidative stress. However, if these antioxidant pathways are overwhelmed from excessive oxidative stress, the oxidative cascade can progress to cell damage and death, resulting in tissue damage, particularly in vascular endothelial tissue [89]. Because of its antioxidant properties, PON-1 may play a role in managing the normal oxidative signaling pathway, and it could serve as a useful biomarker in assessing antioxidant capacity, and by extension, the propensity for systemic inflammation and vascular dysfunction.

In a study of lean, overweight and obese adolescents, decreased levels of PON-1 were associated with central obesity and metabolic syndrome. Additionally, lower levels of PON-1 were associated with hypertension, hypertriglyceridemia, insulin resistance, impaired glucose tolerance, and increased oxidative stress [94]. Another study of women with and without metabolic syndrome showed a negative correlation between PON-1 levels and the presence of CAD in metabolic syndrome patients [96]. CAD is a significant comorbidity in metabolic syndrome, and lower levels of PON-1 could be suggestive of a diminished effectiveness of HDL to attenuate CAD development and progression. Martinelli et al also found that decreased PON-1 levels were associated with metabolic syndrome, with an inverse correlation between PON-1 levels and the severity of metabolic syndrome and its comorbidities [95]. The literature suggests that PON-1, via its antioxidant properties, could play an important role in attenuating the components of metabolic syndrome that arise and progress as a result of oxidative stress.

\section{Discussion}

This paper is an attempt to compile the existing literature of biomarkers with the most substantial evidence of their relationships to metabolic syndrome. Obesity has been classified as a disease state, and this is especially true in the state of West Virginia, where one of the larger cities, Huntington, was listed in a recent CDC report as the most obese in the nation, in the most obese developed country based on average BMI. Thus, a panel of biomarkers that could be used clinically to help predict and establish metabolic syndrome in individuals would be of immense value, not only in treating those that already have the syndrome, but in decreasing the overall prevalence of the disease in the general population. While there have been a number of studies looking at various cytokines and adipokines thought to act as biomarkers for the syndrome, a panel that can be used in clinical practice does not exist. Some have been shown to have greater potential than others, but no single biomarker has been shown to be indicative of metabolic syndrome alone.

Metabolic syndrome is a multifactorial condition that stems from obesity as the causative factor, though the exact mechanism is yet to be determined. Many suggest that oxidative stress, the hallmark of obesity, is linked to a chronic low-grade inflammation. The induced systemic oxidative stress is thought to be at least partly responsible for the dysregulated secretion of adipokines that contributes to metabolic syndrome [9]. Hypertrophied adipocytes generate high levels of ROS which impacts signaling and neighboring perivascular endothelium or resident immune cells [97]. This is compounded by ROS produced from the resultant metabolic derangements such as hyperglycemia and dyslipidemia. Overall, systemic oxidative stress promotes inflammation, results in endothelial dysfunction and altered lipid metabolism, and affects insulin sensitivity (Figure 2).

Leptin, LAR, PAI-1, uric acid, IL-6, TNF- $\alpha$, and OxLDL have all been shown to be elevated in metabolic syndrome, across different populations and generally are correlated with the number of components of metabolic syndrome present. On the other hand, adiponectin, ghrelin, IL-10, and PON-1 have all been shown to be decreased in metabolic syndrome (Table 2). Some ratios, such as HMW- adiponectin: adiponectin and LAR are better predictors than any alone. To date, there is no established panel to test for metabolic syndrome, but this review has compiled a panel of the best candidates.

Furthermore, utilizing the panel as a means of customizing treatment and follow up may be possible given that associations have been shown between each of the biomarkers and lifestyle modifications and medications. Though it is difficult to say whether there is a true causal relationship between medications and alterations of the biomarker levels, these associations can at least guide clinicians (Table 2). Weight loss, which is already known as a treatment for metabolic syndrome, has been shown to result in levels of all the biomarkers normalizing. Metformin, ACEI, and statins have shown similar effects, although data for every single biomarker is not available for each of these drugs/drug classes. 
The potential for using multiple biomarkers for diagnosis and early detection, and subsequent customization of treatment and risk management, is a blossoming field with much room for research. Despite there being many studies on individual biomarkers, there is a void in research on the implications of multiple biomarkers being abnormal. Creat- ing such a panel could provide a relatively easy and minimally-invasive way to detect metabolic syndrome and possibly indicate the severity, depending on the combination of aberrations. Such a panel would be highly useful in locations where metabolic syndrome poses a significant burden, such as West Virginia.

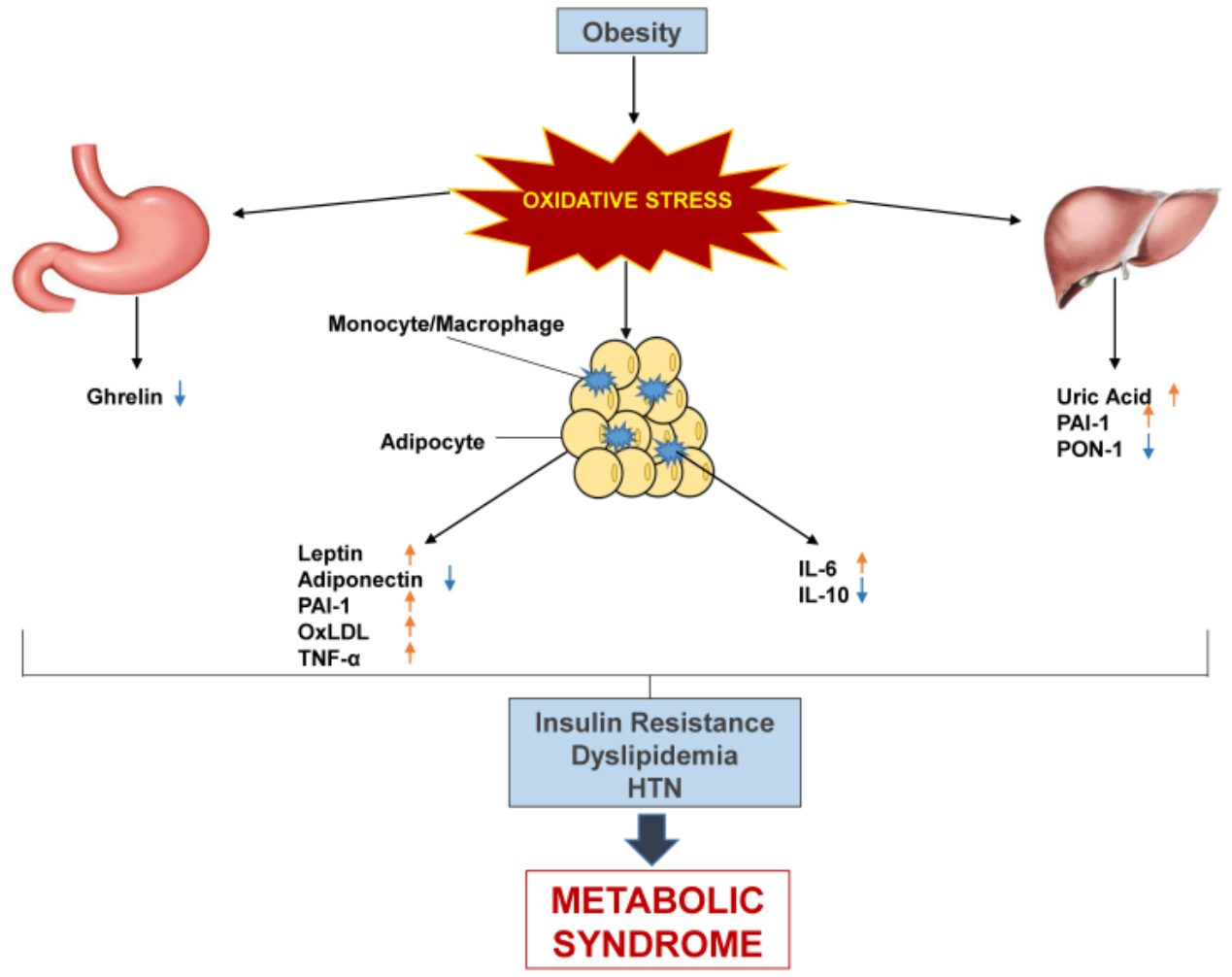

Figure 2: Schematic representation of panel of biomarkers in metabolic syndrome.

Table 2: Biomarker levels in metabolic syndrome and interventions. ACEI- Angiotensin converting enzyme inhibitor; IFN $\beta$ - Interferon- $\beta$

\begin{tabular}{|c|c|c|c|c|c|c|c|}
\hline \multirow[t]{2}{*}{ Biomarker } & \multirow[t]{2}{*}{ Source } & \multirow{2}{*}{$\begin{array}{l}\text { Metabolic } \\
\text { Syndrome }\end{array}$} & \multicolumn{5}{|c|}{ Interventions shown to "normalize" levels } \\
\hline & & & $\begin{array}{l}\text { Lifestyle Modi- } \\
\text { fication }\end{array}$ & Antihypertensive & Diabetic & Lipid Lowering & Other \\
\hline Leptin & $\begin{array}{l}\text { Adipocytes } \\
\text { Cardiomyocyte } \\
\text { Vascular Smooth } \\
\text { Muscle }\end{array}$ & $\uparrow$ & Weight loss [98] & $\begin{array}{l}\text { 1. Hydralazine [99] } \\
\text { 2. Valsartan[100] } \\
\text { 3. Ramipril }[98] \\
\text { 4. Candesartan }[98] \\
\text { 5. Amlodipine[98] } \\
\text { 6. Efonidipine }[101] \\
\text { 7. pindolol }[102] \\
\text { 8. Bunazosin }[103] \\
\text { 9. Methyldopa }[99]\end{array}$ & Metformin [104] & & Bromocriptine [105] \\
\hline Adiponectin & Adipocytes & $\downarrow$ & Weight loss [106] & Valsartan [107] & $\begin{array}{l}\text { 1. Metformin }[108] \\
\text { 2. Sitagliptin }[109] \\
\text { 3. Pioglitazone }[110] \\
\text { 4. Troglitazone }[111] \\
\text { 5. Rosiglitazone }[112] \\
\text { 6. Glimeperide }[113]\end{array}$ & $\begin{array}{l}\text { Atorvastatin } \\
\text { (increases HMW } \\
\text { adiponectin) [114] }\end{array}$ & \\
\hline Ghrelin & Stomach & $\downarrow$ & Weight loss [115] & Valsartan [116] & $\begin{array}{l}\text { 1. Rosiglitazone [117] } \\
\text { 2. Metformin [117] }\end{array}$ & & $\begin{array}{l}\text { 1.Flutamide [118] } \\
\text { 2. Estrogen therapy } \\
\text { [119] }\end{array}$ \\
\hline PAI-1 & $\begin{array}{l}\text { Adipocytes } \\
\text { Hepatocytes } \\
\text { Smooth muscle } \\
\text { cells, } \\
\text { Platelets }\end{array}$ & $\uparrow$ & Weight loss [56] & $\begin{array}{l}\text { 1. Imidapril [120] } \\
\text { 2. Candesartan (cannot } \\
\text { sustain decreased PAI } \\
>4 \text { weeks) [120] }\end{array}$ & $\begin{array}{l}\text { 1. Metformin [121] } \\
\text { 2. Troglitazone [57] }\end{array}$ & Statins [122] & Sibutramine [121] \\
\hline Uric Acid & Liver & $\uparrow$ & Weight loss [123] & 1. Losartan [124] & 1. Metformin [125] & 1.Atorvastatin [126] & 1.Sibutramine [125] \\
\hline
\end{tabular}




\begin{tabular}{|c|c|c|c|c|c|c|c|}
\hline \multirow[t]{2}{*}{ Biomarker } & \multirow[t]{2}{*}{ Source } & \multirow{2}{*}{$\begin{array}{l}\text { Metabolic } \\
\text { Syndrome }\end{array}$} & \multicolumn{5}{|c|}{ Interventions shown to "normalize" levels } \\
\hline & & & $\begin{array}{l}\text { Lifestyle Modi- } \\
\text { fication }\end{array}$ & Antihypertensive & Diabetic & Lipid Lowering & Other \\
\hline & & & & $\begin{array}{l}\text { 2. Calcium Channel } \\
\text { Blockers [124] } \\
\text { 3. ACEI [125] }\end{array}$ & 2.Troglitazone [125] & $\begin{array}{l}\text { 2.Simvastatin [125] } \\
\text { 3.Fenofibrate [125] }\end{array}$ & 2. Orlistat [125] \\
\hline IL-6 & M1 macrophage & $\uparrow$ & Weight loss[127] & $\begin{array}{l}\text { 1.ACEI [128] } \\
\text { 2.Olmesartan [129] }\end{array}$ & Metformin [130] & $\begin{array}{l}\text { 1.Atorvastatin [131] } \\
\text { 2.Pravastatin [132] } \\
\text { 3.Simvastatin [133] }\end{array}$ & $\begin{array}{l}\text { 1.Hydrocortisone [134] } \\
\text { 2.Celecoxib [135] }\end{array}$ \\
\hline TNFa & $\begin{array}{l}\text { Visceral Adipo- } \\
\text { cytes, M1 mac- } \\
\text { rophages }\end{array}$ & $\uparrow$ & Weight loss [127] & Olmesrtan[129] & Metformin [130] & $\begin{array}{l}\text { 1.Atorvastatin [131] } \\
\text { 2.Pravastatin [132] }\end{array}$ & $\begin{array}{l}\text { 1.Orlistat [127] } \\
\text { 2.Hydrocortisone [134] }\end{array}$ \\
\hline IL-10 & $\begin{array}{l}\text { Monocytes, M2 } \\
\text { macrophage }\end{array}$ & $\downarrow$ & Weight loss[136] & & Metformin [130] & Statins [137] & $\begin{array}{l}\text { 1.Triamcinolone [138] } \\
\text { 2.Montelukast [138] } \\
\text { 3.IFN } \beta \text { [139] } \\
\text { 4.Beta 1-3 Glucan [140] }\end{array}$ \\
\hline OxLDL & Adipocytes & $\uparrow$ & $\begin{array}{l}\text { Weight loss [141] } \\
\text { Vegan Diet [142] }\end{array}$ & Fosinopril [143] & & $\begin{array}{l}\text { 1.Statins [144] } \\
\text { 2.Ezetimibe [145] }\end{array}$ & Celecoxib [146] \\
\hline PON-1 & Liver & $\downarrow$ & $\begin{array}{l}\text { Weightloss**(dec } \\
\text { reases pon1) } \\
{[141]}\end{array}$ & Eplerenone [147]) & $\begin{array}{l}\text { 1.Rosiglitazone [148] } \\
\text { 2.Sulfonueras[149] }\end{array}$ & $\begin{array}{l}\text { 1.Fibrates }[150] \\
\text { 2.Statins }([151]) \\
\text { 3. Probucol [152] } \\
\text { 4.Ezetimibe [145] }\end{array}$ & \\
\hline
\end{tabular}

\section{Conclusion}

Metabolic syndrome is a condition with genetic and acquired etiologies that results in CVD complications in populations across the world, but especially in the West Virginian population given the rates of obesity, hypertension, and diabetes. Creating a panel of biomarkers with a known and predictable association with metabolic syndrome can provide a means to detect those at risk and intervene as needed. This could significantly decrease the burden complications impose on patients and the healthcare system.

\section{Acknowledgement}

This work was supported by National Institutes of Health Grants to JIS (HL109015, HL105649 and HL071556), and by the Brickstreet Foundation (J.I.S.). Its contents are solely the responsibility of the authors and do not necessarily represent the official views of the National Institutes of Health.

\section{Competing Interests}

The authors have declared that no competing interest exists.

\section{References}

1. Ford ES. The metabolic syndrome and mortality from cardiovascular disease and all-causes: findings from the National Health and Nutrition Examination Survey II Mortality Study. Atherosclerosis. 2004; 173: 309-14.

2. Aguilar M, Bhuket T, Torres S, Liu B, Wong RJ. Prevalence of the metabolic syndrome in the United States, 2003-2012. Jama. 2015; 313: 1973-4.

3. Grundy SM, Cleeman JI, Daniels SR, Donato KA, Eckel RH, Franklin BA, et al. Diagnosis and management of the metabolic syndrome: an American Heart Association/National Heart, Lung, and Blood Institute scientific statement. Current opinion in cardiology. 2006; 21: 1-6.

4. Alberti KG, Zimmet P, Shaw J. Metabolic syndrome--a new world-wide definition. A Consensus Statement from the International Diabetes Federation. Diabetic medicine : a journal of the British Diabetic Association. 2006; 23: 469-80.

5. Grundy SM, Brewer HB, Jr., Cleeman JI, Smith SC, Jr., Lenfant C, American Heart A, et al. Definition of metabolic syndrome: Report of the National Heart,
Lung, and Blood Institute/American Heart Association conference on scientific issues related to definition. Circulation. 2004; 109: 433-8.

6. Bhandari R, Kelley GA, Hartley TA, Rockett IR. Metabolic syndrome is associated with increased breast cancer risk: a systematic review with meta-analysis. International journal of breast cancer. 2014; 2014: 189384.

7. Ryo M, Nakamura T, Kihara S, Kumada M, Shibazaki S, Takahashi M, et al. Adiponectin as a biomarker of the metabolic syndrome. Circulation journal : official journal of the Japanese Circulation Society. 2004; 68: 975-81.

8. Deng Y, Scherer PE. Adipokines as novel biomarkers and regulators of the metabolic syndrome. Annals of the New York Academy of Sciences. 2010; 1212: E1-E19.

9. Furukawa S, Fujita T, Shimabukuro M, Iwaki M, Yamada Y, Nakajima Y, et al. Increased oxidative stress in obesity and its impact on metabolic syndrome. The Journal of clinical investigation. 2004; 114: 1752-61.

10. Raghavan S, Subramaniyam G, Shanmugam N. Proinflammatory effects of malondialdehyde in lymphocytes. Journal of leukocyte biology. 2012; 92: 1055-67.

11. Fernandez-Sanchez A, Madrigal-Santillan E, Bautista M, Esquivel-Soto J, Morales-Gonzalez A, Esquivel-Chirino C, et al. Inflammation, oxidative stress, and obesity. International journal of molecular sciences. 2011; 12: 3117-32.

12. Mayeux R. Biomarkers: potential uses and limitations. NeuroRx : the journal of the American Society for Experimental NeuroTherapeutics. 2004; 1: 182-8.

13. Dong M, Ren J. What fans the fire: insights into mechanisms of leptin in metabolic syndrome-associated heart diseases. Current pharmaceutical design. 2014; 20: 652-8.

14. Ghantous CM, Azrak Z, Hanache S, Abou-Kheir W, Zeidan A. Differential Role of Leptin and Adiponectin in Cardiovascular System. International journal of endocrinology. 2015; 2015: 534320.

15. Yang R, Barouch LA. Leptin signaling and obesity: cardiovascular consequences. Circulation research. 2007; 101: 545-59.

16. Tardiff JC. Cardiac hypertrophy: stressing out the heart. The Journal of clinical investigation. 2006; 116: 1467-70.

17. Thogersen AM, Soderberg S, Jansson JH, Dahlen G, Boman K, Nilsson TK, et al. Interactions between fibrinolysis, lipoproteins and leptin related to a first myocardial infarction. European journal of cardiovascular prevention and rehabilitation : official journal of the European Society of Cardiology, Working Groups on Epidemiology \& Prevention and Cardiac Rehabilitation and Exercise Physiology. 2004; 11: 33-40.

18. Yoshinaga M, Sameshima K, Tanaka Y, Wada A, Hashiguchi J, Tahara H, et al. Adipokines and the prediction of the accumulation of cardiovascular risk factors or the presence of metabolic syndrome in elementary school children. Circulation journal : official journal of the Japanese Circulation Society. 2008; 72: 1874-8.

19. Lee SW, Jo HH, Kim MR, You YO, Kim JH. Association between metabolic syndrome and serum leptin levels in postmenopausal women. Journal of obstetrics and gynaecology : the journal of the Institute of Obstetrics and Gynaecology. 2012; 32: 73-7.

20. Gannage-Yared MH, Khalife S, Semaan M, Fares F, Jambart S, Halaby G. Serum adiponectin and leptin levels in relation to the metabolic syndrome, androgenic profile and somatotropic axis in healthy non-diabetic elderly men. European journal of endocrinology / European Federation of Endocrine Societies. 2006; 155: 167-76.

21. Yun JE, Kimm H, Jo J, Jee SH. Serum leptin is associated with metabolic syndrome in obese and nonobese Korean populations. Metabolism: clinical and experimental. 2010; 59: 424-9. 
22. Martins Mdo C, Lima Faleiro L, Fonseca A. [Relationship between leptin and body mass and metabolic syndrome in an adult population]. Revista portuguesa de cardiologia : orgao oficial da Sociedade Portuguesa de Cardiologia $=$ Portuguese journal of cardiology : an official journal of the Portuguese Society of Cardiology. 2012; 31: 711-9.

23. Lara-Castro C, Fu Y, Chung BH, Garvey WT. Adiponectin and the metabolic syndrome: mechanisms mediating risk for metabolic and cardiovascular disease. Current opinion in lipidology. 2007; 18: 263-70.

24. Kadowaki T, Yamauchi T, Kubota N, Hara K, Ueki K, Tobe K. Adiponectin and adiponectin receptors in insulin resistance, diabetes, and the metabolic syndrome. The Journal of clinical investigation. 2006; 116: 1784-92.

25. Matsuzawa Y, Funahashi T, Kihara S, Shimomura I. Adiponectin and metabolic syndrome. Arteriosclerosis, thrombosis, and vascular biology. 2004; 24 : 29-33.

26. Spranger J, Kroke A, Mohlig M, Bergmann MM, Ristow M, Boeing H, et al. Adiponectin and protection against type 2 diabetes mellitus. Lancet. 2003; 361: 226-8.

27. Santaniemi M, Kesaniemi YA, Ukkola O. Low plasma adiponectin concentration is an indicator of the metabolic syndrome. European journal of endocrinology / European Federation of Endocrine Societies. 2006; 155: 745-50.

28. Baratta R, Amato S, Degano C, Farina MG, Patane G, Vigneri R, et al. Adiponectin relationship with lipid metabolism is independent of body fat mass: evidence from both cross-sectional and intervention studies. The Journal of clinical endocrinology and metabolism. 2004; 89: 2665-71.

29. Falahi E, Khalkhali Rad AH, Roosta S. What is the best biomarker for metabolic syndrome diagnosis? Diabetes \& metabolic syndrome. 2013.

30. Hara K, Horikoshi M, Yamauchi T, Yago H, Miyazaki O, Ebinuma H, et al. Measurement of the high-molecular weight form of adiponectin in plasma is useful for the prediction of insulin resistance and metabolic syndrome. Diabetes care. 2006; 29: 1357-62.

31. Kotani K, Sakane N. Leptin:adiponectin ratio and metabolic syndrome in the general Japanese population. The Korean journal of laboratory medicine. 2011; 31: $162-6$.

32. Cicero AF, Magni P, More M, Ruscica M, Borghi C, Strollo F, et al. Metabolic syndrome, adipokines and hormonal factors in pharmacologically untreated adult elderly subjects from the Brisighella Heart Study historical cohort. Obesity facts. 2012; 5: 319-26.

33. Finucane FM, Luan J, Wareham NJ, Sharp SJ, O'Rahilly S, Balkau B, et al. Correlation of the leptin:adiponectin ratio with measures of insulin resistance in non-diabetic individuals. Diabetologia. 2009; 52: 2345-9.

34. Cong WN, Golden E, Pantaleo N, White CM, Maudsley S, Martin B. Ghrelin receptor signaling: a promising therapeutic target for metabolic syndrome and cognitive dysfunction. CNS \& neurological disorders drug targets. 2010; 9: 557-63.

35. Varela L, Vazquez MJ, Cordido F, Nogueiras R, Vidal-Puig A, Dieguez C, et al. Ghrelin and lipid metabolism: key partners in energy balance. Journal of molecular endocrinology. 2011; 46: R43-63.

36. Tesauro M, Schinzari F, Rovella V, Di Daniele N, Lauro D, Mores N, et al. Ghrelin restores the endothelin 1 /nitric oxide balance in patients with obesity-related metabolic syndrome. Hypertension. 2009; 54: 995-1000.

37. Pulkkinen L, Ukkola O, Kolehmainen M, Uusitupa M. Ghrelin in diabetes and metabolic syndrome. International journal of peptides. 2010; 2010.

38. Ukkola O, Poykko SM, Antero Kesaniemi Y. Low plasma ghrelin concentration is an indicator of the metabolic syndrome. Annals of medicine. 2006; 38: 274-9.

39. Ukkola O. Ghrelin and metabolic disorders. Current protein \& peptide science. 2009; 10: 2-7.

40. Ukkola O. Ghrelin and the metabolic balance. Journal of endocrinological investigation. 2005; 28: 849-52.

41. Tschop M, Weyer C, Tataranni PA, Devanarayan V, Ravussin E, Heiman ML. Circulating ghrelin levels are decreased in human obesity. Diabetes. 2001; 50: 707-9.

42. Bacha F, Arslanian SA. Ghrelin suppression in overweight children: a manifestation of insulin resistance? The Journal of clinical endocrinology and metabolism. 2005; 90: 2725-30.

43. Fagerberg B, Hulten LM, Hulthe J. Plasma ghrelin, body fat, insulin resistance, and smoking in clinically healthy men: the atherosclerosis and insulin resistance study. Metabolism: clinical and experimental. 2003; 52: 1460-3.

44. McLaughlin T, Abbasi F, Lamendola C, Frayo RS, Cummings DE. Plasma ghrelin concentrations are decreased in insulin-resistant obese adults relative to equally obese insulin-sensitive controls. The Journal of clinical endocrinology and metabolism. 2004; 89: 1630-5.

45. St-Pierre DH, Karelis AD, Coderre L, Malita F, Fontaine J, Mignault D, et al. Association of acylated and nonacylated ghrelin with insulin sensitivity in overweight and obese postmenopausal women. The Journal of clinical endocrinology and metabolism. 2007; 92: 264-9.

46. Binder BR, Christ G, Gruber F, Grubic N, Hufnagl P, Krebs M, et al. Plasminogen activator inhibitor 1: physiological and pathophysiological roles. News in physiological sciences : an international journal of physiology produced jointly by the International Union of Physiological Sciences and the American Physiological Society. 2002; 17: 56-61.

47. Kraja AT, Province MA, Arnett D, Wagenknecht L, Tang W, Hopkins PN, et al Do inflammation and procoagulation biomarkers contribute to the metabolic syndrome cluster? Nutrition \& metabolism. 2007; 4: 28.
48. Paganelli F, Alessi MC, Morange P, Maixent JM, Levy S, Vague IJ. Relationship of plasminogen activator inhibitor-1 levels following thrombolytic therapy with rt-PA as compared to streptokinase and patency of infarct related coronary artery. Thrombosis and haemostasis. 1999; 82: 104-8.

49. Kruithof EK, Gudinchet A, Bachmann F. Plasminogen activator inhibitor 1 and plasminogen activator inhibitor 2 in various disease states. Thrombosis and haemostasis. 1988; 59: 7-12.

50. Malgorzewicz S, Skrzypczak-Jankun E, Jankun J. Plasminogen activator inhibitor-1 in kidney pathology (Review). International journal of molecular medicine. 2013; 31: 503-10.

51. Juhan-Vague I, Alessi MC, Mavri A, Morange PE. Plasminogen activator inhibitor-1, inflammation, obesity, insulin resistance and vascular risk. Journal of thrombosis and haemostasis : JTH. 2003; 1: 1575-9.

52. Bilgili S, Celebiler AC, Dogan A, Karaca B. Inverse relationship between adiponectin and plasminogen activator inhibitor-1 in metabolic syndrome patients. Endocrine regulations. 2008; 42: 63-8.

53. Vague P, Juhan-Vague I, Aillaud MF, Badier C, Viard R, Alessi MC, et al Correlation between blood fibrinolytic activity, plasminogen activator inhibitor level, plasma insulin level, and relative body weight in normal and obese subjects. Metabolism: clinical and experimental. 1986; 35: 250-3.

54. Sakkinen PA, Wahl P, Cushman M, Lewis MR, Tracy RP. Clustering of procoagulation, inflammation, and fibrinolysis variables with metabolic factors in insulin resistance syndrome. American journal of epidemiology. 2000; 152: 897-907.

55. Alessi MC, Juhan-Vague I. PAI-1 and the metabolic syndrome: links, causes, and consequences. Arteriosclerosis, thrombosis, and vascular biology. 2006; 26: 2200-7.

56. Folsom AR, Qamhieh HT, Wing RR, Jeffery RW, Stinson VL, Kuller LH, et al. Impact of weight loss on plasminogen activator inhibitor (PAI-1), factor VII, and other hemostatic factors in moderately overweight adults. Arteriosclerosis and thrombosis : a journal of vascular biology / American Heart Association. 1993; 13: 162-9.

57. Kruszynska YT, Yu JG, Olefsky JM, Sobel BE. Effects of troglitazone on blood concentrations of plasminogen activator inhibitor 1 in patients with type 2 diabetes and in lean and obese normal subjects. Diabetes. 2000; 49: 633-9.

58. Billiet L, Doaty S, Katz JD, Velasquez MT. Review of hyperuricemia as new marker for metabolic syndrome. ISRN rheumatology. 2014; 2014: 852954

59. McGillicuddy FC, de la Llera Moya M, Hinkle CC, Joshi MR, Chiquoine EH, Billheimer JT, et al. Inflammation impairs reverse cholesterol transport in vivo. Circulation. 2009; 119: 1135-45.

60. Ishizaka N, Ishizaka $Y$, Toda E, Nagai R, Yamakado M. Association between serum uric acid, metabolic syndrome, and carotid atherosclerosis in Japanese individuals. Arteriosclerosis, thrombosis, and vascular biology. 2005; 25: 1038-44.

61. Silva HA, Carraro JC, Bressan J, Hermsdorff $\mathrm{HH}$. Relation between uric acid and metabolic syndrome in subjects with cardiometabolic risk. Einstein. 2015; 13: $202-8$.

62. Clausen JO, Borch-Johnsen $\mathrm{K}$, Ibsen $\mathrm{H}$, Pedersen $\mathrm{O}$. Analysis of the relationship between fasting serum uric acid and the insulin sensitivity index in a population-based sample of 380 young healthy Caucasians. European journal of endocrinology / European Federation of Endocrine Societies. 1998; 138: 63-9.

63. Rathmann W, Funkhouser E, Dyer AR, Roseman JM. Relations of hyperuricemia with the various components of the insulin resistance syndrome in young black and white adults: the CARDIA study. Coronary Artery Risk Development in Young Adults. Annals of epidemiology. 1998; 8: 250-61.

64. Tsunoda S, Kamide K, Minami J, Kawano Y. Decreases in serum uric acid by amelioration of insulin resistance in overweight hypertensive patients: effect of a low-energy diet and an insulin-sensitizing agent. American journal of hypertension. 2002; 15: 697-701.

65. Khitan Z, Kim DH. Fructose: a key factor in the development of metabolic syndrome and hypertension. Journal of nutrition and metabolism. 2013; 2013: 682673.

66. Johnson RJ, Segal MS, Sautin Y, Nakagawa T, Feig DI, Kang DH, et al. Potential role of sugar (fructose) in the epidemic of hypertension, obesity and the metabolic syndrome, diabetes, kidney disease, and cardiovascular disease. The American journal of clinical nutrition. 2007; 86: 899-906.

67. de Oliveira EP, Burini RC. High plasma uric acid concentration: causes and consequences. Diabetology \& metabolic syndrome. 2012; 4: 12

68. Viazzi F, Garneri D, Leoncini G, Gonnella A, Muiesan ML, Ambrosioni E, et al. Serum uric acid and its relationship with metabolic syndrome and cardiovascular risk profile in patients with hypertension: insights from the I-DEMAND study. Nutrition, metabolism, and cardiovascular diseases : NMCD. 2014; 24: 921-7.

69. Puig JG, Martinez MA. Hyperuricemia, gout and the metabolic syndrome. Current opinion in rheumatology. 2008; 20: 187-91.

70. Chen LY, Zhu WH, Chen ZW, Dai HL, Ren JJ, Chen JH, et al. Relationship between hyperuricemia and metabolic syndrome. Journal of Zhejiang University Science B. 2007; 8: 593-8.

71. Ford ES, Li C, Cook S, Choi HK. Serum concentrations of uric acid and the metabolic syndrome among US children and adolescents. Circulation. 2007; 115: 2526-32

72. Soukup M, Biesiada I, Henderson A, Idowu B, Rodeback D, Ridpath L, et al. Salivary uric acid as a noninvasive biomarker of metabolic syndrome. Diabetology \& metabolic syndrome. 2012; 4: 14. 
73. Chiou WK, Wang MH, Huang DH, Chiu HT, Lee YJ, Lin JD. The relationship between serum uric acid level and metabolic syndrome: differences by sex and age in Taiwanese. Journal of epidemiology / Japan Epidemiological Association. 2010; 20: 219-24.

74. Rodrigues SL, Baldo MP, Capingana P, Magalhaes P, Dantas EM, Molina Mdel $\mathrm{C}$, et al. Gender distribution of serum uric acid and cardiovascular risk factors: population based study. Arquivos brasileiros de cardiologia. 2012; 98: 13-21.

75. Aroor AR, McKarns S, Demarco VG, Jia G, Sowers JR. Maladaptive immune and inflammatory pathways lead to cardiovascular insulin resistance. Metabolism: clinical and experimental. 2013; 62: 1543-52.

76. Weiss TW, Arnesen H, Seljeflot I. Components of the interleukin-6 transsignalling system are associated with the metabolic syndrome, endothelial dysfunction and arterial stiffness. Metabolism: clinical and experimental. 2013; 62: 1008-13.

77. Chedraui P, Escobar GS, Perez-Lopez FR, Palla G, Montt-Guevara M, Cecchi E, et al. Angiogenesis, inflammation and endothelial function in postmenopausal women screened for the metabolic syndrome. Maturitas. 2014; 77: 370-4.

78. Indulekha K, Surendar J, Mohan V. High sensitivity C-reactive protein, tumor necrosis factor-alpha, interleukin-6, and vascular cell adhesion molecule-1 levels in Asian Indians with metabolic syndrome and insulin resistance (CURES-105). Journal of diabetes science and technology. 2011; 5: 982-8.

79. Kim HJ, Higashimori T, Park SY, Choi H, Dong J, Kim YJ, et al. Differential effects of interleukin-6 and -10 on skeletal muscle and liver insulin action in vivo. Diabetes. 2004; 53: 1060-7.

80. Musialik K. The influence of chosen adipocytokines on blood pressure values in patients with metabolic syndrome. Kardiologia polska. 2012; 70: 1237-42.

81. Balasoiu M, Balasoiu AT, Stepan AE, Dinescu SN, Avramescu CS, Dumitrescu $\mathrm{D}$, et al. Proatherogenic adipocytokines levels in metabolic syndrome. Romanian journal of morphology and embryology = Revue roumaine de morphologie et embryologie. 2014; 55: 29-33.

82. Gormez S, Demirkan A, Atalar F, Caynak B, Erdim R, Sozer V, et al. Adipose tissue gene expression of adiponectin, tumor necrosis factor-alpha and leptin in metabolic syndrome patients with coronary artery disease. Internal medicine. 2011; 50: 805-10.

83. van Exel E, Gussekloo J, de Craen AJ, Frolich M, Bootsma-Van Der Wiel A, Westendorp RG, et al. Low production capacity of interleukin-10 associates with the metabolic syndrome and type 2 diabetes : the Leiden 85-Plus Study. Diabetes. 2002; 51: 1088-92

84. Calcaterra V, De Amici M, Klersy C, Torre C, Brizzi V, Scaglia F, et al. Adiponectin, IL-10 and metabolic syndrome in obese children and adolescents. Acta bio-medica : Atenei Parmensis. 2009; 80: 117-23.

85. Esposito K, Pontillo A, Giugliano F, Giugliano G, Marfella R, Nicoletti G, et al. Association of low interleukin-10 levels with the metabolic syndrome in obese women. The Journal of clinical endocrinology and metabolism. 2003; 88: $1055-8$.

86. Chen LX, Zhang SD, Zhu LL, Sun M. [Association of metabolic syndrome with serum interleukin- 10 and high sensitive $C$ reactive protein(hs-CRP) in old men]. Zhong nan da xue xue bao Yi xue ban = Journal of Central South University Medical sciences. 2008; 33: 970-4.

87. Choi KM, Ryu OH, Lee KW, Kim HY, Seo JA, Kim SG, et al. Serum adiponectin, interleukin-10 levels and inflammatory markers in the metabolic syndrome. Diabetes research and clinical practice. 2007; 75: 235-40.

88. Nishida M, Moriyama T, Sugita $Y$, Yamauchi-Takihara K. Interleukin-10 associates with adiponectin predominantly in subjects with metabolic syndrome. Circulation journal : official journal of the Japanese Circulation Society. 2007; 71: 1234-8.

89. Landar A, Zmijewski JW, Dickinson DA, Le Goffe C, Johnson MS, Milne GL, et al. Interaction of electrophilic lipid oxidation products with mitochondria in endothelial cells and formation of reactive oxygen species. American journal of physiology Heart and circulatory physiology. 2006; 290: H1777-87.

90. Pohjantahti-Maaroos H, Palomaki A, Kankkunen P, Laitinen R, Husgafvel S, Oksanen K. Circulating oxidized low-density lipoproteins and arterial elasticity: comparison between men with metabolic syndrome and physically active counterparts. Cardiovascular diabetology. 2010; 9: 41.

91. Kelly AS, Jacobs DR, Jr., Sinaiko AR, Moran A, Steffen LM, Steinberger J. Relation of circulating oxidized LDL to obesity and insulin resistance in children. Pediatric diabetes. 2010; 11: 552-5.

92. Sigurdardottir V, Fagerberg B, Hulthe J. Circulating oxidized low-density lipoprotein (LDL) is associated with risk factors of the metabolic syndrome and LDL size in clinically healthy 58-year-old men (AIR study). Journal of internal medicine. 2002; 252: 440-7.

93. Holvoet P, Lee DH, Steffes M, Gross M, Jacobs DR, Jr. Association between circulating oxidized low-density lipoprotein and incidence of the metabolic syndrome. Jama. 2008; 299: 2287-93.

94. Krzystek-Korpacka M, Patryn E, Hotowy K, Czapinska E, Majda J, Kustrzeba-Wojcicka I, et al. Paraoxonase (PON)-1 activity in overweight and obese children and adolescents: association with obesity-related inflammation and oxidative stress. Advances in clinical and experimental medicine : official organ Wroclaw Medical University. 2013; 22: 229-36.

95. Martinelli N, Micaglio R, Consoli L, Guarini P, Grison E, Pizzolo F, et al. Low levels of serum paraoxonase activities are characteristic of metabolic syndrome and may influence the metabolic-syndrome-related risk of coronary artery disease. Experimental diabetes research. 2012; 2012: 231502.
96. Yilmaz H, Sayar N, Yilmaz M, Gurkan U, Sesal C, Tosu R, et al. Serum paraoxonase 1 activity in women with metabolic syndrome. Kardiologia polska. 2010; 68: 1219-24.

97. Le Lay S, Simard G, Martinez MC, Andriantsitohaina R. Oxidative stress and metabolic pathologies: from an adipocentric point of view. Oxidative medicine and cellular longevity. 2014; 2014: 908539.

98. Koh KK, Park SM, Quon MJ. Leptin and cardiovascular disease: response to therapeutic interventions. Circulation. 2008; 117: 3238-49.

99. Anato V, Garmendia JV, Bianco NE, De Sanctis JB. Antihypertensive treatment decreased serum leptin levels in severe preeclampsia during pregnancy. Annals of nutrition \& metabolism. 2001; 45: 190-2.

100. Fogari R, Derosa G, Zoppi A, Rinaldi A, Lazzari P, Fogari E, et al. Comparison of the effects of valsartan and felodipine on plasma leptin and insulin sensitivity in hypertensive obese patients. Hypertension research : official journal of the Japanese Society of Hypertension. 2005; 28: 209-14.

101. Koh KK, Quon MJ, Lee SJ, Han SH, Ahn JY, Kim JA, et al. Efonidipine simultaneously improves blood pressure, endothelial function, and metabolic parameters in nondiabetic patients with hypertension. Diabetes care. 2007; 30: 1605-7.

102. Ficek J, Kokot F, Chudek J, Adamczak M, Ficek R, Wiecek A. Influence of antihypertensive treatment with perindopril, pindolol or felodipinon plasma leptin concentration in patients with essential hypertension. Hormone and metabolic research $=$ Hormon- und Stoffwechselforschung $=$ Hormones et metabolisme. 2002; 34: 703-8.

103. Thara S, Shimamoto K, Watanabe H, Sakai R, Kawana M. An alpha1-receptor blocker reduces plasma leptin levels in hypertensive patients with obesity and hyperleptinemia. Hypertension research : official journal of the Japanese Society of Hypertension. 2006; 29: 805-11.

104. Glueck CJ, Fontaine RN, Wang P, Subbiah MT, Weber K, Illig E, et al. Metformin reduces weight, centripetal obesity, insulin, leptin, and low-density lipoprotein cholesterol in nondiabetic, morbidly obese subjects with body mass index greater than 30. Metabolism: clinical and experimental. 2001; 50: 856-61.

105. Kok P, Roelfsema F, Frolich M, van Pelt J, Meinders AE, Pijl H. Activation of dopamine D2 receptors lowers circadian leptin concentrations in obese women. The Journal of clinical endocrinology and metabolism. 2006; 91: 3236-40.

106. Huang F, Del-Rio-Navarro BE, Perez-Ontiveros JA, Ruiz-Bedolla E, Saucedo-Ramirez OJ, Villafana S, et al. Effect of six-month lifestyle intervention on adiponectin, resistin and soluble tumor necrosis factor-alpha receptors in obese adolescents. Endocrine journal. 2014; 61: 921-31.

107. Lee JM, Kim JH, Son HS, Hong EG, Yu JM, Han KA, et al. Valsartan increases circulating adiponectin levels without changing HOMA-IR in patients with type 2 diabetes mellitus and hypertension. The Journal of international medical research. 2010; 38: 234-41.

108. Miazgowski T, Dziwura-Ogonowska J, Safranow K, Iskierska K, Widecka K. Changes in adiponectin level and fat distribution in patients with type 2 diabetes. European journal of clinical investigation. 2014; 44: 192-9.

109. Hibuse T, Maeda N, Kishida K, Kimura T, Minami T, Takeshita E, et al. A pilot three-month sitagliptin treatment increases serum adiponectin level in Japanese patients with type 2 diabetes mellitus--a randomized controlled trial START-J study. Cardiovascular diabetology. 2014; 13: 96.

110. Sam S, Haffner S, Davidson MH, D'Agostino R, Sr., Perez A, Mazzone T. Pioglitazone-mediated changes in lipoprotein particle composition are predicted by changes in adiponectin level in type 2 diabetes. The Journal of clinical endocrinology and metabolism. 2012; 97: E110-4.

111. Phillips SA, Ciaraldi TP, Kong AP, Bandukwala R, Aroda V, Carter L, et al. Modulation of circulating and adipose tissue adiponectin levels by antidiabetic therapy. Diabetes. 2003; 52: 667-74.

112. Kim SG, Ryu OH, Kim HY, Lee KW, Seo JA, Kim NH, et al. Effect of rosiglitazone on plasma adiponectin levels and arterial stiffness in subjects with prediabetes or non-diabetic metabolic syndrome. European journal of endocrinology / European Federation of Endocrine Societies. 2006; 154: 433-40.

113. Li CJ, Zhang JY, Yu DM, Zhang QM. Adding glimepiride to current insulin therapy increases high-molecular weight adiponectin levels to improve glycemic control in poorly controlled type 2 diabetes. Diabetology \& metabolic syndrome. 2014; 6: 41.

114. von Eynatten M, Liu D, Bluemm A, Schuster T, Baumann M, Lutz J, et al. Changes in adiponectin multimer distribution in response to atorvastatin treatment in patients with type 2 diabetes. Clinical endocrinology. 2009; 71: $27-32$.

115. Stoeckli R, Chanda R, Langer I, Keller U. Changes of body weight and plasma ghrelin levels after gastric banding and gastric bypass. Obesity research. 2004; 12: $346-50$

116. Meric C, Aydogdu A, Tasci I, Deniz F, Baysan O, Serdar M, et al. Effects of valsartan treatment on serum ghrelin level and left ventricular mass index in patients with untreated primary hypertension. Anadolu kardiyoloji dergisi : AKD = the Anatolian journal of cardiology. 2014; 14: 234-8.

117. Kadoglou NP, Tsanikidis H, Kapelouzou A, Vrabas I, Vitta I, Karayannacos $\mathrm{PE}$, et al. Effects of rosiglitazone and metformin treatment on apelin, visfatin, and ghrelin levels in patients with type 2 diabetes mellitus. Metabolism: clinical and experimental. 2010; 59: 373-9.

118. Gambineri A, Pagotto U, Tschop M, Vicennati V, Manicardi E, Carcello A, et al. Anti-androgen treatment increases circulating ghrelin levels in obese 
women with polycystic ovary syndrome. Journal of endocrinological investigation. 2003; 26: 629-34.

119. Kellokoski E, Poykko SM, Karjalainen AH, Ukkola O, Heikkinen J, Kesaniemi YA, et al. Estrogen replacement therapy increases plasma ghrelin levels. The Journal of clinical endocrinology and metabolism. 2005; 90: 2954-63.

120. Fogari R, Zoppi A, Mugellini A, Maffioli P, Lazzari P, Derosa G. Role of angiotensin II in plasma PAI-1 changes induced by imidapril or candesartan in hypertensive patients with metabolic syndrome. Hypertension research : official journal of the Japanese Society of Hypertension. 2011; 34: 1321-6.

121. Koiou E, Tziomalos K, Katsikis I, Delkos D, Tsourdi EA, Panidis D. Disparate effects of pharmacotherapy on plasma plasminogen activator inhibitor-1 levels in women with the polycystic ovary syndrome. Hormones. 2013; 12: 559-66.

122. Laufs U, Wassmann S, Schackmann S, Heeschen C, Bohm M, Nickenig G. Beneficial effects of statins in patients with non-ischemic heart failure. Zeitschrift fur Kardiologie. 2004; 93: 103-8.

123. Nicholls A, Scott JT. Effect of weight-loss on plasma and urinary levels of uric acid. Lancet. 1972; 2: 1223-4.

124. Choi HK, Soriano LC, Zhang Y, Rodriguez LA. Antihypertensive drugs and risk of incident gout among patients with hypertension: population based case-control study. Bmj. 2012; 344: d8190.

125. Tsouli SG, Liberopoulos EN, Mikhailidis DP, Athyros VG, Elisaf MS. Elevated serum uric acid levels in metabolic syndrome: an active component or an innocent bystander? Metabolism: clinical and experimental. 2006; 55: 1293-301.

126. Athyros VG, Elisaf M, Papageorgiou AA, Symeonidis AN, Pehlivanidis AN, Bouloukos VI, et al. Effect of statins versus untreated dyslipidemia on serum uric acid levels in patients with coronary heart disease: a subgroup analysis of the GREek Atorvastatin and Coronary-heart-disease Evaluation (GREACE) study. American journal of kidney diseases : the official journal of the National Kidney Foundation. 2004; 43: 589-99.

127. Samuelsson L, Gottsater A, Lindgarde F. Decreasing levels of tumour necrosis factor alpha and interleukin 6 during lowering of body mass index with orlistat or placebo in obese subjects with cardiovascular risk factors. Diabetes, obesity \& metabolism. 2003; 5: 195-201.

128. Gullestad L, Aukrust P, Ueland T, Espevik T, Yee G, Vagelos R, et al. Effect of high- versus low-dose angiotensin converting enzyme inhibition on cytokine levels in chronic heart failure. Journal of the American College of Cardiology. 1999; 34: 2061-7.

129. Fliser D, Buchholz K, Haller $\mathrm{H}$, Olmesartan EUTo, Pravastatin in I, Atherosclerosis I. Antiinflammatory effects of angiotensin II subtype 1 receptor blockade in hypertensive patients with microinflammation. Circulation. 2004; 110: 1103-7.

130. Hyun B, Shin S, Lee A, Lee S, Song Y, Ha NJ, et al. Metformin Down-regulates TNF-alpha Secretion via Suppression of Scavenger Receptors in Macrophages. Immune network. 2013; 13: 123-32.

131. Sola S, Mir MQ, Lerakis S, Tandon N, Khan BV. Atorvastatin improves left ventricular systolic function and serum markers of inflammation in nonischemic heart failure. Journal of the American College of Cardiology. 2006; 47: 332-7.

132. Freeman DJ, Norrie J, Sattar N, Neely RD, Cobbe SM, Ford I, et al. Pravastatin and the development of diabetes mellitus: evidence for a protective treatment effect in the West of Scotland Coronary Prevention Study. Circulation. 2001; 103: 357-62.

133. Rezaie-Majd A, Maca T, Bucek RA, Valent P, Muller MR, Husslein P, et al. Simvastatin reduces expression of cytokines interleukin-6, interleukin-8, and monocyte chemoattractant protein-1 in circulating monocytes from hypercholesterolemic patients. Arteriosclerosis, thrombosis, and vascular biology. 2002; 22: 1194-9.

134. DeRijk RH, Petrides J, Deuster P, Gold PW, Sternberg EM. Changes in corticosteroid sensitivity of peripheral blood lymphocytes after strenuous exercise in humans. The Journal of clinical endocrinology and metabolism. 1996; 81: 228-35.

135. Abbasi SH, Hosseini F, Modabbernia A, Ashrafi M, Akhondzadeh S. Effect of celecoxib add-on treatment on symptoms and serum IL-6 concentrations in patients with major depressive disorder: randomized double-blind placebo-controlled study. Journal of affective disorders. 2012; 141: 308-14.

136. Jung SH, Park HS, Kim KS, Choi WH, Ahn CW, Kim BT, et al. Effect of weight loss on some serum cytokines in human obesity: increase in IL-10 after weight loss. The Journal of nutritional biochemistry. 2008; 19: 371-5.

137. Liakopoulos OJ, Dorge H, Schmitto JD, Nagorsnik U, Grabedunkel J, Schoendube FA. Effects of preoperative statin therapy on cytokines after cardiac surgery. The Thoracic and cardiovascular surgeon. 2006; 54: 250-4.

138. Stelmach I, Jerzynska J, Kuna P. A randomized, double-blind trial of the effect of glucocorticoid, antileukotriene and beta-agonist treatment on IL-10 serum levels in children with asthma. Clinical and experimental allergy : journal of the British Society for Allergy and Clinical Immunology. 2002; 32: 264-9.

139. Krakauer M, Sorensen P, Khademi M, Olsson T, Sellebjerg F. Increased IL-10 mRNA and IL-23 mRNA expression in multiple sclerosis: interferon-beta treatment increases IL-10 mRNA expression while reducing IL-23 mRNA expression. Multiple sclerosis. 2008; 14: 622-30.

140. Sarinho E, Medeiros D, Schor D, Rego Silva A, Sales V, Motta ME, et al. Production of interleukin-10 in asthmatic children after Beta-1-3-glucan. Allergologia et immunopathologia. 2009; 37: 188-92.

141. Rector RS, Warner SO, Liu Y, Hinton PS, Sun GY, Cox RH, et al. Exercise and diet induced weight loss improves measures of oxidative stress and insulin sensitivity in adults with characteristics of the metabolic syndrome. American journal of physiology Endocrinology and metabolism. 2007; 293: E500-6.

142. Elkan AC, Sjoberg B, Kolsrud B, Ringertz B, Hafstrom I, Frostegard J. Gluten-free vegan diet induces decreased LDL and oxidized LDL levels and raised atheroprotective natural antibodies against phosphorylcholine in patients with rheumatoid arthritis: a randomized study. Arthritis research \& therapy. 2008; 10: R34.

143. Hayek T, Attias J, Coleman R, Brodsky S, Smith J, Breslow JL, et al. The angiotensin-converting enzyme inhibitor, fosinopril, and the angiotensin II receptor antagonist, losartan, inhibit LDL oxidation and attenuate atherosclerosis independent of lowering blood pressure in apolipoprotein $\mathrm{E}$ deficient mice. Cardiovascular research. 1999; 44: 579-87.

144. Vasankari T, Ahotupa M, Toikka J, Mikkola J, Irjala K, Pasanen P, et al. Oxidized LDL and thickness of carotid intima-media are associated with coronary atherosclerosis in middle-aged men: lower levels of oxidized LDL with statin therapy. Atherosclerosis. 2001; 155: 403-12.

145. Turfaner N, Uzun H, Balci H, Ercan MA, Karter YH, Caner M, et al. Ezetimibe therapy and its influence on oxidative stress and fibrinolytic activity. Southern medical journal. 2010; 103: 428-33.

146. Chenevard R, Hurlimann D, Bechir M, Enseleit F, Spieker L, Hermann M, et al. Selective COX-2 inhibition improves endothelial function in coronary artery disease. Circulation. 2003; 107: 405-9.

147. Noll C, Messaoudi S, Milliez P, Samuel JL, Delcayre C, Janel N. Eplerenone administration has beneficial effect on hepatic paraoxonase 1 activity in diabetic mice. Atherosclerosis. 2010; 208: 26-7.

148. Carreon-Torres E, Rendon-Sauer K, Monter-Garrido M, Toledo-Ibelles P, Gamboa R, Menjivar M, et al. Rosiglitazone modifies HDL structure and increases HDL-apo AI synthesis and catabolic rates. Clinica chimica acta; international journal of clinical chemistry. 2009; 401: 37-41.

149. Wojcicka G, Jamroz-Wisniewska A, Marciniak A, Lowicka E, Beltowski J. The differentiating effect of glimepiride and glibenclamide on paraoxonase 1 and platelet-activating factor acetylohydrolase activity. Life sciences. 2010; 87: 126-32.

150. Gouedard C, Koum-Besson N, Barouki R, Morel Y. Opposite regulation of the human paraoxonase-1 gene PON-1 by fenofibrate and statins. Molecular pharmacology. 2003; 63: 945-56.

151. Costa LG, Giordano G, Furlong CE. Pharmacological and dietary modulators of paraoxonase 1 (PON1) activity and expression: the hunt goes on. Biochemical pharmacology. 2011; 81: 337-44.

152. Hong SC, Zhao SP, Wu ZH. Probucol up-regulates paraoxonase 1 expression in hepatocytes of hypercholesterolemic rabbits. Journal of cardiovascular pharmacology. 2006; 47: 77-81. 